\title{
Triging Student Learning Results with Utilizing Google Classroom and Zoom Platform
}

\section{Wayan Eka Mahendra1}

${ }^{1}$ Hotel Management Study Program, Institut Pariwisata dan Bisnis Internasional, Indonesia

\section{A R T I C L E I N F O}

Article history:

Received March 08, 2021

Revised March 11, 2021

Accepted April 30, 2021

Available online May 25, 2021

Kata Kunci:

Hasil Belajar, Google

Classroom, Zoom

Keywords:

achievement, google

classroom, zoom

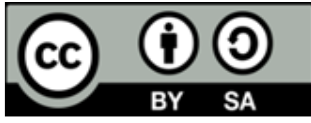

This is an open access article under the CC BY-SA license.

Copyright $@ 2021$ by Author. Published by Universitas Pendidikan Ganesha.

\section{A B S T R A C T}

During the pandemic, online learning has been carried out almost all over the world, making it mandatory for teachers to have skills in creating fun online learning for students. Teachers still find it challenging to choose an online learning platform that can facilitate students ' learning. This study aims to analyze the differences in student science learning outcomes between students who take online learning using a combination of google classroom and zoom and students who take online learning with the WA group. This study involved a sample of 92 students who were taken by a simple random sampling technique. Data on students' science learning outcomes were collected using tests that had previously been tested for content validity, empirical validity, and reliability coefficients. The collected data were analyzed using one-way covariance analysis by first testing the normality of the data distribution, the linearity of the regression line, and the homogeneity of variance. The results of this study indicate differences in science learning outcomes between students who take online learning a combination of google classroom and zoom with students who take online learning with WA group after controlling for the initial knowledge variable with an average learning outcome of 73.17 and 58.76. It can be concluded that students who take online learning a combination of google classroom and zoom can improve student learning outcomes. This research implies that teachers can use google classroom and zoom as platforms for online learning.

\section{INTRODUCTION}

Since first appearing in the city of Wuhan at the end of 2019 (Roosa et al., 2020; Yulia, 2020). Covid-19 is responsible for a deadly pandemic worldwide (Stoecklin et al., 2020). Less than six months since it was discovered, this virus has been reported to infect 190 countries (Jain et al., 2021; Sari et al., 2020) including Indonesia. Some policies were carried out by the Indonesian government to prevent the 
spread of Covid-19, such as: social distancing, physical distancing, large-scale social restrictions (PSBB) based on Government Regulation number 4 of 2020, effective from 1 April 2020. The consequences of this decision also have an impact on the education sector, such as the policy of the Ministry of Education and Culture in implementing distance learning/learning from home/online learning by issuing Circular Letter Number 4 of 2020 (Ardini et al., 2020; Ayuni et al., 2021; Wulandari \& Purwanta, 2021). The circular letter regarding government policies in education sector while emergency period of the corona virus disease (Covid-19), one of which includes online or distance education. This learning changes the paradigm from knowledge transfer in the classroom to the virtual classroom (Chen \& Li, 2011; Liang et al., 2011). During pandemic situation, online learning has been carried out almost all over the world (Goldschmidt, 2020). In Indonesia, online learning implements with some application such as ruang guru, class rooms, zoom, google classrooms, google forms, or via WhatsApp groups. This situation indirectly forces and demands teachers to be able to use technological sophistication in learning.

Teachers are required to have competence in utilizing learning technology, especially the internet (e-learning) in order to be able to take advantage of knowledge, technology, and information to do their duties as a teacher and build the competence of students (Baber, 2021; Sadikin \& Hamidah, 2020). The same thing also happened in class VI SD Gugus 6 Batubulan, especially in science learning. Most of the teachers make use of the WA group for online learning. Starting with sending a weekly schedule, then followed by a learning video, and ending with the work of assignments that must be sent privately to the WA teacher. The focus of using technology in the e-learning process for focused on making learning easier and more effective so that students will be competent to access learning material via computer networks (Dong et al., 2020; Sayıner \& Ergönül, 2021; Shetu et al., 2021). The World Economic Forum in 2017 also states that teachers must be able to understand three key points of educational progress, namely competence, character and literacy (Schwab \& Sala-i-Martín, 2017). Indirect online learning also requires teachers to increase their digital literacy. Digital literacy is defined as the knowledge and skills to use digital media, communication tools or networks in finding, evaluating, using, making information, and take advantage of healthy, wise, intelligent, accurate, correct, and law-abiding manner in order to foster communication and interaction in daily life (Jang et al., 2021; Khairunnisa \& Ilmi, 2020). With good digital literacy, teachers will be competent to teach online learning by using various learning management systems (LMS), such as: Moodle, schoology, google classroom, google meet, zoom and others (Alshammari, 2020; Baber, 2021). Not only take advantage of WhatsApp groups with student's parent. Of course, this is a certain task for the teacher, because they have to manually organize the student assignments in the WA group, and this definitely makes work more difficult (Anugrahana, 2020; Rosidah, 2020).

Online learning is done online, using learning applications and social networks (Kurtz et al., 2014; Nácher et al., 2021; Solehana et al., 2019). This learning is done without face to face, but through an available platform (Kyewski \& Krämer, 2018; Valverde-Berrocoso et al., 2020). During the implementation of the online model, students have the flexibility of time to learn. Students can learn anytime and anywhere without being limited by space and time. Students can also interact with the teacher simultaneously, such as using video calls or live chat. All subject matter forms are disseminated online, communication is also carried out online, and tests are also carried out online. Discussions via WA group really help users to communicate online (Sidiq, 2019), but are limited to chat. Of course, this learning is not effective and has many weaknesses. Using WA for learning system has been complained by some students, because of the short interaction and teachers tend to give more assignments, it's make the reason for students feel overwhelmed to do tasks (Daheri et al., 2020; Kusuma \& Hamidah, 2020; Susanti, 2020).

For this reason, it is important to find other solutions for online learning can run effectively and can improve the outcomes learning. One of the platforms that can be used is google classroom and zoom. Google classroom is a kind of mixed learning method that began in 2014 which considers the achievement of certain functions such as simplifying student-teacher communication, as well as the ease of distributing and assessing assignments (Al-Maroof \& Al-Emran, 2018; Mahitsa \& Mahardini, 2020). Which can increase classroom productivity, and can make it easier for teachers to manage learning and deliver information appropriately and accurately to students (Azhar \& Iqbal, 2018; Hakim, 2016). Meanwhile, zoom is also believed by stakeholders to be an effective platform in online learning, however, need awareness of this online learning can lead to fatigue (Mpungose, 2021). With the combination of these two features, it is hoped that it will be able to facilitate online learning until it will lead to increasing student science learning outcomes.

Previous research stated that the google classroom platform was effectively used for online learning (Santosa et al., 2020; Soni et al., 2018). The findings of previous research also stated that google classroom provides features that can be used in learning to make learning effective (Daniati et al., 2020; Permata \& Bhakti, 2020). Other research also states that zoom applications are also effective in online 
learning (Kusuma \& Hamidah, 2020; Mpungose, 2021; Suhery et al., 2020). Get Keyword that google classroom can be used as an online learning platform. There is no study on the triggers for increasing student learning outcomes by utilizing the Google Classroom and Zoom platforms. This study aims to analyze the benefits of using the google classroom platform and zooming in on student learning outcomes. It is hoped that the Google Classroom and Zoom platforms can help students learn online.

\section{METHOD}

This research was conducted on grade VI student in SD Negeri Gugus 6 Batubulan which aims to compare student's science learning outcomes in the online learning period using a combination of google classroom and zoom using the WA group after controlling for student's prior knowledge. Researchers cannot exclusively control other variables that have affect student's science learning outcomes, accordingly this research is classified as a quasi-experimental design with a non-equivalent control group design. The research design is placed in Figure 1. Involving a sample of 92 people who were taken by simple random sampling technique. The data was collected from student's score on science learning outcomes using tests that were compiled by the researcher. This learning outcome covers a test which consists of 10 essays has previously been tested for validity through content validity using Gregory (Mahendra et al., 2019) with a content validity coefficient of 0.80 and empirical validity using moment product correlation (Field, 2013). While the reliability coefficient is calculated using the Alpha Cronbach formula because it is in the form of an essay test (Mahendra et al., 2019) and the result shows 0.762 . The collected data were analyzed using one-way analysis of covariant (ANCOVA) parametric statistics which had previously been tested for the normality of the data distribution, the regression direction linearity test, and the variance homogeneity test. All research data analysis uses the help of the IBM SPSS statistics 26 program.

\begin{tabular}{lllll}
\hline Experiment Group & $\longrightarrow$ & $\mathrm{X}_{1}$ & $\longrightarrow$ & $\mathrm{O}_{1}$ \\
\hline Control Group & $\longrightarrow$ & $\mathrm{X}_{2}$ & $\longrightarrow$ & $\mathrm{O}_{2}$ \\
\hline
\end{tabular}

Figure 1. Non Equivalen Control Group Design

\section{RESULT AND DISCUSSION}

Result

The difference in student's science learning outcomes as a result of online learning interventions using the various LMS available becomes object of this study. Specifically using LMS is separated into two, namely application combination of google classroom and zoom which is called the experimental group and the use of the WA group which is called the control group. With the research design nonequivalent control group design and parametric statistics in the form of one-way ANCOVA test as a data analysis tool. The data in this study are grouped into science learning outcomes of students who take learning with a combination of google classroom and zoom, science learning outcomes of students who take lessons with the WA group, and data on student's prior knowledge. The results of the analysis center data measurement (mean, mode, median) and data distribution measurement (variance and standard deviation) on the science learning outcomes score and student's prior knowledge. The normality test is carried out to ensure that the statistical test used in testing the hypothesis can actually be done. This is important, because if the data is not normally distributed, then the t-test which is a parametric statistic cannot be done (Field, 2013).

The normality test in this study used the Kolmogorov-Smirnov module at the output of IBM SPSS statistics 26 on the two groups of data on student's science learning outcomes. The Kolmogorov-Smirnov test analysis represent that sig. $>0.05$ for two data groups, such as data on student's science learning outcomes in the experimental group $\left(\mathrm{Y}_{1}\right)$ and the control group $\left(\mathrm{Y}_{2}\right)$ as in the table above. That means $\mathrm{H}_{0}$ is accepted (failed to be rejected), both sample groups are normally distributed. The prerequisites for covariance analysis include: (1) the independent variable or covariate $X$ has a linear effect on the dependent variable $\mathrm{Y},(2)$ the covariate $\mathrm{X}$ has a linear effect on the dependent variable which is same in all cells formed by the factor (one multifactor) that is reviewed, and (3) the factor or multi-factor that is reviewed or used as the independent variable has no effect on covariate X. At the same with criteria or prerequisites, the $\mathrm{X}$ covariate is measured or observed before the measurement of the factors or multifactors is carried out. 
The results of the linearity test $(\mathrm{Y} 1 * \mathrm{X} 1)$ between the experimental group science learning outcomes data (Y1) and the experimental group's initial knowledge data (X1), it can be seen that the Deviation from Linearity module has a sig value. $>0.05$ or $0.848>0.05$. It's means that the learning outcome data and the experimental group's prior knowledge have a linear relation. Besides that, the Linearity module represent sig value. $<0.05$ or $0.038<0.05$; which means having a meaningful connection. This it can be concluded that the learning outcome data and the experimental group's prior knowledge have a linear and useful connection. The results of the linearity test (Y2*X2) between the control group's science learning outcomes data (Y2) and the control group's initial knowledge data (X2), namely the Deviation from Linearity module has a sig value $>0.05$ or $0.291>0.05$. That means the learning outcome data and the control group's beginning knowledge have a linear connection. Meanwhile, the Linearity module shows the sig value. $<0.05$ or $0.001<0.05$; that has a meaningful relation. Thus, it can be concluded that the learning outcome data and the experimental group's prior knowledge have a linear and meaningful connection.

Homogeneity variance test that has been done to ensure that the differences obtained from oneway ANCOVA test really came from differences between groups, not due to differences within groups (Field, 2013). From the results of the analysis of the variance homogeneity test using IBM SPSS statistics 26. The base on mean module explains that a good analysis result must obtain sig. $>0.05$ for science learning outcomes data and students' preliminary knowledge data, each of them has a value $0.664>0.05$; and $0.382>0.05$. It can be concluded that the two groups of science learning outcomes and student`s prior knowledge come from populations that have the same or homogeneous variance. Based on the results of the prerequisite test, specifically the data distribution normality test, the linearity test and the meaning of the regression direction, and the homogeneity test of variance, it can be concluded that the student learning outcomes data comes from a population that is normally distributed, linear and meaningful, and also has the same or homogeneous variance. Therefore, it is possible to test the hypothesis with one-way ANCOVA. The significance value for the covariable of student's beginning knowledge is obtained by sig value of 0.001 and this sig value less than $0.05(0.01<0.05)$, that means, it has linear connection between prior knowledge and student science learning outcomes. This implies that Ancova's one-way assumption has been accepted.

First, this test is carried out by eliminating the effect of using the platform in learning. From the results of data analysis, it can be seen that the sig. to change the platform in learning is 0.001 which is less than 0.05 ; so that $\mathrm{H}_{0}$ is rejected and $\mathrm{H}_{1}$ is accepted. So, it can be concluded that there are differences in science learning outcomes between students who take online learning combined with google classroom and zoom and students who take online learning with the WA group after controlling the prior knowledge variable. To determine the effect of prior knowledge and different learning platforms used on student learning outcomes in science simultaneously using the corrected model module. It can be seen that the significance value is 0.001 which is far below the 0.05 value. So, it can be concluded that simultaneously the student's prior knowledge and the learning platform used have an effect on students' science learning outcomes. Data analysis represent the group of students who took online learning using a combination of LMS google classroom and zoom had an average science learning result score of 73.173; while the group of students who took part in online learning using the WA group had an average score of 58.760 science learning outcomes. That means, the average science learning outcomes of the group of students who took online learning using a combination of LMS google classroom and zoom were higher than the average science learning outcomes of the group of students who took online learning with the WA group.

The results of data analysis indicate the advantages of online learning using a combination of LMS google classroom and zoom compared with using WA group on science learning outcomes. Online learning makes learning activities more flexible (El-Magboub et al., 2016; Shetu et al., 2021; Yulia, 2020). With a more innovative learning process, students are more motivated to learn. Online learning using Zoom allows students to meet face-to-face virtually so that learning becomes more real (Mansyur, 2020; Mpungose, 2021; Windhiyana, 2020). Beginning with a meeting using zoom, students can come face to face virtually about the learning process that will be practiced. The teacher creates a class in google classroom, then invites students via email from each student or through the class code from the google classroom that has been created. Learning materials are uploaded by using the option in "about", then the materials are uploaded through "add materials". To notify students when material has been uploaded, use the "stream" option, then select "announcement" on the "+" sign. Add tasks by selecting "assignments" on the "+" sign. Adding questions to google classroom can select "question" on the "+" sign. The material uploaded on Zoom is systematically sorted to make it easier for students to learn (Kusuma \& Hamidah, 2020; Suhery et al., 2020).

This does not happen when learning uses the WA group. The teacher uploads learning videos and assignments that must be done and collected by personal WA to the teacher. That isn`t effective, because 
students only learn with under controlling of their parents (Daheri et al., 2020; Kusuma \& Hamidah, 2020; Susanti, 2020). Students rarely or never meet face-to-face virtually with their teachers (Widiyono, 2020; Yoga Purandina \& Astra Winaya, 2020). Teachers also cannot monitor the students' activities while studying at home. Even though several studies have suggested learning by WA group is most favored by students in online learning (Zhafira et al., 2020). Good learning is learning that makes students feel comfortable in learning. In addition, teachers are also required to unite student activities during online learning so that teachers know the difficulties faced by students (Mustakim, 2020; Tchen et al., 2018; Tsai et al., 2018).

Previous research stated that online learning using some online platforms has resulted: very effective (23.3\%), practical (46.7\%), moderate (20\%), and ineffective (10\%) (Mustakim, 2020). Other research also states that it is better to do virtual face-to-face learning to increase the effectiveness of other learning (Alhefnawi, 2021; Amiti, 2020; Şendağ \& Ferhan Odabaşi, 2009). Combines an online learning platform without a virtual meet and a platform with a virtual meet. So, it is not wrong if the students' science learning outcomes in the experimental group are better than the science learning outcomes of students in the control group. Some studies also explain about using google classroom platform in online learning can improve student learning outcomes, problem solving skills, mathematical reasoning, and learning motivation (Gunawan \& Sunarman, 2018; Nirfayanti \& Nurbaeti, 2019; Pradana, 2017; Santosa et al., 2020). It can be concluded that online learning by using the right platform will increase student comfort in learning and affect student learning outcomes. This research implies that teachers can use google classroom and zoom as platforms for online learning.

\section{CONCLUSION}

There are differences in science learning outcomes between students who take online learning using a combination of LMS google classroom and zoom and learning only using WA group after controlling the prior knowledge variable. It is recommended that teachers use the google classroom platform in implementing online learning with a virtual meet combination in order to get better learning outcomes.

\section{REFERENCES}

Al-Maroof, R. A. S., \& Al-Emran, M. (2018). Students Acceptance of Google Classroom: An Exploratory Study using PLS-SEM Approach. International Journal of Emerging Technologies in Learning (IJET), 13(06), 112-123. https://doi.org/10.3991/ijet.v13i06.8275.

Alhefnawi, M. A. M. (2021). Assessing the efficacy of online handouts and active lectures in learning outcomes at the engineering undergraduate level. Ain Shams Engineering Journal, xxxx. https: //doi.org/10.1016/j.asej.2021.02.012.

Alshammari, M. T. (2020). Evaluation of gamification in e-learning systems for elementary school students. TEM Journal, 9(2). https://doi.org/https://doi.org/10.18421/TEM92-51.

Amiti, F. (2020). Synchronous and asynchronous E-learning. European Journal of Open Education and ELearning Studies, 5(2), 60-70. https://doi.org/10.46827/ejoe.v5i2.3313.

Anugrahana, A. (2020). Hambatan, Solusi dan Harapan: Pembelajaran Daring Selama Masa Pandemi Covid-19 Oleh Guru Sekolah Dasar. Scholaria: Jurnal Pendidikan Dan Kebudayaan, 10(3), 282-289.

Ardini, L., Iswara, U. S., \& Retnani, E. D. (2020). Efektivitas Penggunaan E-Learning Sebagai Media Pembelajaran Saat Pandemi Covid 19. JKBM:Jurnal Konsep Bisnis Dan Manajemen, 7(1), 72-81. https://doi.org/10.31289/jkbm.v7i1.4333.

Ayuni, D., Marini, T., Fauziddin, M., \& Pahrul, Y. (2021). Kesiapan Guru TK Menghadapi Pembelajaran Daring Masa Pandemi Covid-19. Jurnal Obsesi: Jurnal Pendidikan Anak Usia Dini, 5(1). https: //doi.org/https://doi.org/10.31004/obsesi.v5i1.579.

Azhar, K. A., \& Iqbal, N. (2018). Effectiveness of Google Classroom: Teachers' Perceptions. PRIZREN SOCIAL SCIENCE JOURNAL, 2(2), 52-66.

Baber, H. (2021). Modelling the acceptance of e-learning during the pandemic of COVID-19-A study of South Korea. The International Journal of Management Education, 19(2). https://doi.org/https://doi.org/10.1016/j.ijme.2021.100503.

Chen, E., \& Li, Z. (2011). On the application of multimedia technology in foreign language teaching and learning in China's colleges: Challenges, problems and implications. 2011 International Conference on Multimedia Technology, ICMT 2011, 595-597. https://doi.org/10.1109/ICMT.2011.6001903.

Daheri, M., Juliana, J., Deriwanto, D., \& Amda, A. D. (2020). Efektifitas WhatsApp sebagai Media Belajar 
Daring. Jurnal Basicedu, 4(4), 775-783. https://doi.org/10.31004/basicedu.v4i4.445.

Daniati, D., Ismanto, B., \& Luhsasi, D. I. (2020). Upaya Peningkatan Motivasi dan Hasil Belajar Mahasiswa dengan Penerapan Model Pembelajaran E-Learning Berbasis Google Classroom pada Masa Pandemi Covid-19. Jurnal Kependidikan: Jurnal Hasil Penelitian Dan Kajian Kepustakaan Di Bidang Pendidikan, Pengajaran Dan Pembelajaran, 6(3), 601. https://doi.org/10.33394/jk.v6i3.2642.

Dong, C., Cao, S., \& Li, H. (2020). Young children's online learning during COVID-19 pandemic: Chinese parents' beliefs and attitudes. Children and Youth Services Review, 118(June), 105440. https://doi.org/10.1016/j.childyouth.2020.105440.

El-Magboub, A., Haworth, I. S., Sutch, B. T., \& Romero, R. M. (2016). Evaluation of in-class and online discussion meetings in a biopharmaceutics problem-based learning class. Currents in Pharmacy Teaching and Learning, 8(6), 811-820. https://doi.org/10.1016/j.cptl.2016.08.021.

Field, A. (2013). Discovering Statistics Using IBM SPSS Statistics. SAGE Publications Ltd.

Goldschmidt, K. (2020). The COVID-19 Pandemic: Technology use to Support the Wellbeing of Children. Journal of Pediatric Nursing, 53, 88-90. https://doi.org/10.1016/j.pedn.2020.04.013.

Gunawan, F. I., \& Sunarman, S. G. (2018). Pengembangan Kelas Virtual Dengan Google Classroom Dalam Keterampilan Pemecahan Masalah (Problem Solving) Topik Vektor Pada Siswa Smk Untuk Mendukung Pembelajaran. Prosiding Seminar Nasional Pendidikan Matematika Etnomatnesia, $O(0)$.

Hakim, A. B. (2016). Efektifitas Penggunaan E-learning Moodle, Google Classroom Dan Edmodo. Jurnal IStatement, 2(1), 1-6. http://garuda.ristekbrin.go.id/documents/detail/501942.

Jain, R., Gupta, M., Jain, K., \& Kang, S. (2021). Deep learning based prediction of COVID-19 virus using chest X-Ray. Journal of Interdisciplinary Mathematics, 24(1), 155-173. https://doi.org/10.1080/09720502.2020.1833460.

Jang, M., Aavakare, M., Nikou, S., \& Kim, S. (2021). The impact of literacy on intention to use digital technology for learning: A comparative study of Korea and Finland. Telecommunications Policy, 45(7). https://doi.org/https://doi.org/10.1016/j.telpol.2021.102154.

Khairunnisa, G. F., \& Ilmi, Y. I. N. (2020). Media Pembelajaran Matematika Konkret Versus Digital: Systematic Literature Review di Era Revolusi Industri 4.0. Jurnal Tadris Matematika, 3(2). https://doi.org/https://doi.org/10.21274/jtm.2020.3.2.131-140.

Kurtz, G., Tsimerman, A., \& Steiner, O. (2014). The Flipped Classroom Answer to Future Learning? European Journal of Open, Distance and E-Learning, 17(2). https://doi.org/https://doi.org/10.2478/eurodl-2014-0027.

Kusuma, J. W., \& Hamidah. (2020). Perbandingan Hasil Belajar Matematika Dengan Penggunaan Platform Whatsapp Group Dan Webinar Zoom Dalam Pembelajaran Jarak Jauh Pada Masa Pandemik Covid 19. Jurnal Ilmiah Pendidikan Matematika, 5(1), 97-106. https://doi.org/https://doi.org/10.26877/jipmat.v5i1.5942.

Kyewski, E., \& Krämer, N. C. (2018). gamify or not to gamify? An experimental field study of the influence of badges on motivation, activity, and performance in an online learning course. Computers \& Education, 118, 25-37. https://doi.org/https://doi.org/10.1016/j.compedu.2017.11.006.

Liang, Y., Zheng, T., \& Wang, M. (2011). English audio-visual teaching mode and its teaching environment construction - Henan Institute of Science and Technology as the example. 2011 International Conference on Multimedia Technology, 3050-3053. https://doi.org/10.1109/ICMT.2011.6001924

Mahendra, I. W. E., Parmithi, N. N., Suana, I. W., \& Sumandya, I. W. (2019). Developing Hots Through Performance Assessment. International Journal of Scientific \& Technology Research, 8(12), 30043007.

Mahitsa, M., \& Mahardini, A. (2020). Analisis Situasi Penggunaan Google Classroom pada Pembelajaran Daring Fisika. Jurnal Pendidikan FIsika, VIII(2), 215-224. https://doi.org/http://dx.doi.org/10.24127/jpf.v8i2.3102 ANALISIS.

Mansyur, A. R. (2020). Dampak COVID-19 Terhadap Dinamika Pembelajaran Di Indonesia. Education and Learning Journal, 1(2), 113. https://doi.org/10.33096/eljour.v1i2.55.

Mpungose, C. B. (2021). Lecturers' reflections on use of Zoom video conferencing technology for elearning at a South African university in the context of coronavirus. African Identities. https://doi.org/10.1080/14725843.2021.1902268.

Mustakim, M. (2020). Efektivitas Pembelajaran Daring Menggunakan Media Online Selama Pandemi Covid-19 Pada Mata Pelajaran Matematika. Al Asma: Journal of Islamic Education, 2(1), 1-12. https://doi.org/10.24252/asma.v2i1.13646.

Nácher, M. J., Badenes-Ribera, L., Torrijos, C., Ballesteros, M. A., \& Cebadera, E. (2021). The effectiveness of the GoKoan e-learning platform in improving university students' academic performance. Studies in Educational Evaluation, 70. https://doi.org/https://doi.org/10.1016/j.stueduc.2021.101026. 
Nirfayanti, N., \& Nurbaeti, N. (2019). Pengaruh Media Pembelajaran Google Classroom Dalam Pembelajaran Analisis Real Terhadap Motivasi Belajar Mahasiswa. Proximal: Jurnal Penelitian Matematika Dan Pendidikan Matematika, 2(1), 50-59. https://doi.org/10.30605/2615-7667.211.

Permata, A., \& Bhakti, Y. B. (2020). Keefektifan Virtual Class dengan Google Classroom dalam Pembelajaran Fisika Dimasa Pandemi Covid-19. JIPFRI (Jurnal Inovasi Pendidikan Fisika Dan Riset Ilmiah), 4(1), 27-33. https://doi.org/10.30599/jipfri.v4i1.669.

Pradana, D. B. P. (2017). Pengaruh Penerapan Tools Google Classroom pada Model Pembelajaran Project Based Learning terhadap Hasil Belajar Siswa. IT-Edu: Jurnal Information Technology and Education, 2(01).

Roosa, K., Lee, Y., Luo, R., Kirpich, A., Rothenberg, R., Hyman, J. M., Yan, P., \& Chowell, G. (2020). Real-time forecasts of the COVID-19 epidemic in China from February 5th to February 24th, 2020. Infectious Disease Modelling, 5, 256-263. https://doi.org/10.1016/j.idm.2020.02.002.

Rosidah, A. (2020, March). Pemanfaatan Google Classroom Untuk Pembelajaran Online - LPMP DKI Jakarta. LPMP DKI Jakarta.

Sadikin, A., \& Hamidah, A. (2020). Pembelajaran Daring di Tengah Wabah Covid-19. Biodik, 6(2), 109-119. https://doi.org/10.22437/bio.v6i2.9759.

Santosa, F. H., Negara, H. R. P., \& Samsul Bahri. (2020). Efektivitas Pembelajaran Google Classroom Terhadap Kemampuan Penalaran Matematis Siswa. Jurnal Pemikiran Dan Penelitian Pendidikan Matematika (JP3M), 3(1), 62-70. https://doi.org/10.36765/jp3m.v3i1.254.

Sari, I., Sinaga, P., Hernani, \& Solfarina. (2020). Chemistry Learning via Distance Learning during the Covid-19 Pandemic. TADRIS (Journal of Education and Teacher Training), 5(1). https://doi.org/https://doi.org/10.24042/tadris.v5i1.6346.

Sayıner, A. A., \& Ergönül, E. (2021). E-learning in clinical microbiology and infectious diseases. Clinical Microbiology and Infection, 28. https://doi.org/https://doi.org/10.1016/j.cmi.2021.05.010.

Schwab, K., \& Sala-i-Martín, X. (2017). The Global Competitiveness Report 2017-2018.

Şendağ, S., \& Ferhan Odabaşi, H. (2009). Effects of an online problem based learning course on content knowledge acquisition and critical thinking skills. Computers and Education, 53(1), 132-141. https://doi.org/10.1016/j.compedu.2009.01.008.

Shetu, S. F., Rahman, M. M., Ahmed, A., Mahin, M. F., Akib, M. A. U., \& Saifuzzaman, M. (2021). Impactful elearning framework: A new hybrid form of education. Current Research in Behavioral Sciences, 2(April), 100038. https://doi.org/10.1016/j.crbeha.2021.100038.

Sidiq, R. (2019). Pemanfaatan Whatsapp Group Dalam Pengimplementasian Nilai-Nilai Karakter Pancasila Pada Era Disrupsi. Puteri Hijau: Jurnal Pendidikan Sejarah, 4(2), 154. https://doi.org/10.24114/ph.v4i2.16304.

Solehana, L., Asrori, A., \& Usman, A. (2019). The Development of E-Learning Teaching Material Based on Edmodo on Basic Competencies of National Integration at Class X of Senior High School. Journal Of Education, Teaching And Learning, 4(2). https://doi.org/https://doi.org/10.26737/jetl.v4i2.1914.

Soni, Hafid, Hayami, Fatma, Wenando, Amien, Fuad, Unik, \& Mukhtar. (2018). Optimalisasi Penggunaan Google Classroom, E-Learning \& Blended Learning sebagai Media Pembelajaran Bagi Guru dan Siswa di SMK Negeri 1 Bangkinang. Jurnal Pengabdian Untukmu Negeri, 21. https://doi.org/https://doi.org/10.37859/jpumri.v2i1.361.

Stoecklin, S. B., Rolland, P., Silue, Y., Mailles, A., Campese, C., Simondon, A., Mechain, M., Meurice, L., Nguyen, M., Bassi, C., Yamani, E., Behillil, S., Ismael, S., Nguyen, D., Malvy, D., Lescure, F. X., Georges, S., Lazarus, C., Tabai, A., ... Levy-Bruhl, D. (2020). First cases of coronavirus disease 2019 (COVID19) in France: Surveillance, investigations and control measures, January 2020. Eurosurveillance, 25(6), 2000094. https://doi.org/10.2807/1560-7917.ES.2020.25.6.2000094.

Suhery, Putra, \& Jasmalinda. (2020). Sosialisasi Penggunaan Aplikasi Zoom Meeting dan Google Classroom Pada Guru Di SDN 17 Mata Air Padang Selatan. Jurnal Inovasi Penelitian, 1(3), 129-132. https: //stp-mataram.e-journal.id/JIP.

Susanti. (2020). The Use of WhatsApp in Reading Lesson at the STMIK Pontianak, West Kalimantan, Indonesia. Mimbar Pendidikan, https: //ejournal.upi.edu/index.php/mimbardik/article/view/24151/11694.

Tchen, P., Leung, L., Simpson, F., Kim-Sing, A., \& Pearson, M. L. (2018). Bridging the gap: An evaluation of self-paced online transition modules for advanced pharmacy practice experience students. Currents in Pharmacy Teaching and Learning, 10(10). https: //doi.org/https://doi.org/10.1016/j.cptl.2018.07.006.

Tsai, Y., Lin, C., Hong, J., \& Tai, K. (2018). The effects of metacognition on online learning interest and continuance to learn with MOOCs. Computers \& Education, 121. https://doi.org/https://doi.org/10.1016/j.compedu.2018.02.011. 
Valverde-Berrocoso, Garrido-Arroyo, M. d., Burgos-Videla, C., \& Morales-Cevallos. (2020). Trends in Educational Research about e-Learning: A Systematic Literature Review. Sustainability, 12(12). https://doi.org/https://doi.org/10.3390/su12125153.

Widiyono, A. (2020). Efektifitas Perkuliahan Daring (Online) pada Mahasiswa PGSD di Saat Pandemi Covid 19. Jurnal Pendidikan, 8(2), 169-177. https://doi.org/10.36232/pendidikan.v8i2.458.

Windhiyana, E. (2020). Dampak Covid-19 Terhadap Kegiatan Pembelajaran Online Di Perguruan Tinggi Kristen Di Indonesia. Perspektif Ilmu Pendidikan, 34(1), 1-8. https://doi.org/10.21009/pip.341.1.

Wulandari, H., \& Purwanta, E. (2021). Pencapaian Perkembangan Anak Usia Dini di Taman Kanak-kanak selama Pembelajaran Daring di Masa Pandemi Covid-19. Jurnal Obsesi : Jurnal Pendidikan Anak Usia Dini, 5(1). https://doi.org/https://doi.org/10.31004/obsesi.v5i1.626.

Yoga Purandina, I. P., \& Astra Winaya, I. M. (2020). Pendidikan Karakter di Lingkungan Keluarga Selama Pembelajaran Jarak Jauh pada Masa Pandemi COVID-19. Cetta: Jurnal Ilmu Pendidikan, 3(2), 270290. https://doi.org/10.37329/cetta.v3i2.454.

Yulia, H. (2020). Online Learning to Prevent the Spread of Pandemic Corona Virus in Indonesia. ETERNAL (English Teaching Journal), 11(1). https://doi.org/https://doi.org/10.26877/eternal.v11i1.6068.

Zhafira, N. H., Ertika, Y., \& Chairiyaton, C. (2020). Persepsi Mahasiswa Terhadap Perkuliahan Daring Sebagai Sarana Pembelajaran Selama Masa Karantina Covid-19. Jurnal Bisnis Dan Kajian Strategi Manajemen, 4(1), 37-45. https://doi.org/https://doi.org/10.35308/jbkan.v4i1.1981. 